\title{
COMPARISON OF RADIOFREQUENCY ABLATION AND CURETTAGE IN OSTEOID OSTEOMA IN CHILDREN
}

\section{COMPARAÇÃO ENTRE ABLAÇÃO POR RADIOFREQUÊNCIA E CURETAGEM DE OSTEOMA OSTEOIDE EM CRIANÇAS}

\author{
Ferd Göksel ${ }^{1}$, Ayșe AyCan $^{2}$, Cenk ERmutlu ${ }^{3}$, Umut Hatay Gölge ${ }^{1}$, Bartu Sarisözen ${ }^{2}$ \\ 1. Canakkale Onsekiz Mart University, School of Medicine, Department of Orthopaedics and Traumatology, Canakkale, Turkey. \\ 2. Uludağ University, School of Medicine, Department of Orthopaedics and Traumatology, Bursa, Turkey. \\ 3. İstanbul Training and Reserch Hospital, Department of Orthopaedics and Traumatology, istanbul, Turkey.
}

\section{ABSTRACT}

Objective: Osteoid osteoma, which is observed in the adolescent and young adult population as benign bone tumors, appears as a single nidus with a diameter $<2 \mathrm{~cm}$ and is treated with open surgery. However, technological advances in medicine have made it possible to apply less invasive procedures in surgery. Methods: Between 2006-2014, 24 patients < 18 years of age were treated for osteoid osteoma. Patient demographic data, surgical data, complications, and recurrences were noted. Results: Twenty-four patients (mean age, 11 [2-18] years) were treated and followed up for a mean 3.58 (range, 1-9) years. Mean patient age in the curettage group was 12.1 (range, 3-18) years. Mean operation length was 69.5 (range, 60-120) minutes. Mean hospital stay was 1.3 (range, 0-2) days. Mean patient age in the radiofrequency ablation (RFA) group was 10.7 (range, 2-17) years. Five patients were female and 8 were male. Mean operation length was 49.6 (range, 20-90) minutes. Mean hospital stay was 0.3 (range, 0-1) days. Mean follow-up time was 1.76 (range, 1-4) years. Mean operation length, hospital stay, and follow-up were significantly shorter in the RFA group. Conclusions: Considering reduced costs due to shorter hospitalization periods and the ability to reach anatomically difficult locations, percutaneous procedures are likely to replace the conventional open approach. Level of evidence: II, retrospective study.

Keywords: Osteoid osteoma. Hospital stay. Complication.

\section{RESUMO}

Objetivo: O osteoma osteoide, tumor ósseo benigno, acomete predominantemente adolescentes e adultos jovens. É descrito como um nicho único menor que 2 centímetros e o tratamento, nas últimas décadas, era realizado por cirurgia aberta. Com os avanços tecnológicos na medicina, os procedimentos menos invasivos tornaram-se o tratamento de escolha. Métodos: Entre 2006 e 2014, 24 pacientes com menos de 18 anos foram submetidos ao tratamento de osteoma osteoide. Foram coletados os dados demográficos da população estudada e as informações sobre a cirurgia, complicações e recorrência. Resultados: Os vinte e quatro pacientes com média de idade de 11 anos (2-18) foram tratados e o acompanhamento teve média de 3,58 anos (1-9). A média de idade dos pacientes no Grupo curetagem foi de 12,1 anos (3-18). O tempo médio da cirurgia foi de 69,5 minutos (60-120). A média de permanência hospitalar foi de 1,3 dias (0-2). A média de idade dos pacientes no Grupo ARF foi de 10,7 anos (2-17) anos, sendo cinco do sexo feminino e oito do sexo masculino. O tempo médio de cirurgia foi de 49,6 minutos (20-90). A permanência hospitalar média foi de 0,3 dias (0-1). O tempo médio de acompanhamento foi de 1,76 anos (1-4). As médias de tempo cirúrgico, tempo de internação e acompanhamento foram significativamente menores no Grupo ARF. Conclusões: Quando a redução de custos promovida pelo menor tempo de hospitalização e a capacidade de atingir locais anatomicamente difíceis também forem considerados, os procedimentos percutâneos provavelmente substituirão a cirurgia aberta convencional. Nível de evidência II; Estudo retrospectivo.

Descritores: Osteoma Osteoide. Tempo de internação. Complicações.

Citation: Göksel F, Aycan A, Ermutlu C, Gölge UH, Sarısözen B. Comparison of radiofrequency ablation and curettage in osteoid osteoma in children. Acta Ortop Bras. [online]. 2019;27(2):100-3. Available from URL: http://www.scielo.br/aob.

\section{INTRODUCTION}

Osteoid osteoma is the third most common bone tumour. It is generally observed in the long bones of the lower extremities, especially in the adolescent and young adult population. Histologically, it is described by a single nidus formed by osteoblasts and endowed with neural and vascular supply. The lesion is typically smaller than 2 centimeters.
The most common symptom is pain, which is discontinuous in the beginning but gradually getting constant. Symptoms increase at night and generally alleviated by oral non steroidal anti inflammatory drugs(NSAID) medication. Plain radiographs and computer tomography $(\mathrm{CT})$ scan are usually enough for diagnosis. ${ }^{1-4}$ Bone

All authors declare no potential conflict of interest related to this article. 
scintigraphy, single photon emission CT or magnetic resonance imaging(MRI) may be indicated in some cases. ${ }^{2-4}$

Osteoid osteomas tend to regress within 6 to 15 years without treatment. This can be reduced to 2 to 3 years with the use of acetyIsalicylic acid and NSAIDs. However, most patients do not comply with long term medication because of gastrointestinal side effects or frustration. ${ }^{3-5}$ For years, the alternative to medical treatment had been surgical resection or curettage. Recently, percutaneous interventions such as radiofrequency ablation(RFA), trephine excision, cryoablation and laser thermocoagulation have been introduced. ${ }^{4-6}$ The aim of this study is to compare the results of conventional surgical treatment with those of RFA in children and adolescents. The participants of the research are signed the Term of Free and Informed Consents. Our article hasn't got ethics committee approval.because it isn't compulsory in retrospective studies.

\section{MATERIALS AND METHODS}

Twenty four patients under 18 years of age who were treated because of osteoid osteoma between years 2006 and 2014 in our institution were included in this retrospective study. Patients with less than 1 year of follow-up, those who had first presented with recurrence and those with vertebral lesions were excluded. Patient's age, gender, location of the tumour, type of intervention, date, duration, pathological results, hospitalization time, complications and recurrence if any were noted. Patients were grouped into two based on type of treatment; those who had curettage and those who were treated with RFA. Operation length, hospitalisation length, complication and, recurrence and success rates were compared between two groups.

\section{Operative procedure}

Patients were placed supine on the radiolucent operating table. Both procedures were performed under general anesthesia with fluoroscopic guidance. Patients were discharged once their postoperative pain was manageable with oral analgesic only. Patients were allowed to mobilize freely.

Following standard soft tissue dissection, site of the bony lesion was exposed. Exact location of the lesion was confirmed with fluoroscopy. Thin layers of bone were removed tangentially using gauges till nidus was visualized. Nidus and the surrounding reactive tissue were curetted and sent for pathological examination.(Figure 1) For the RFA method, exact location of the lesion was determined prior to a stab incision. The bone was drilled using a 3-4 mm drill bit. RF probe (Cool-tip RF Ablation System, Covidien,USA)was placed inside the bone tunnel created and it was made sure that the probe was inside the lesion. Ablation was performed at $90 \mathrm{C}$ for 6 minutes.(Figure 2)

Descriptive statistics, chi-square and Mann-Whitney-U tests were used to compare variables. Data were analysed with SPSS statistical software (SPSS, Chicago, USA)

\section{RESULTS}

Mean age of patients was 11(2-18) years. Eight (33\%) of the patients were female and $16(66 \%)$ were male. $54.2 \%$ of the lesions were in the femur, $29.2 \%$ in the tibia and $16.7 \%$ in other locations (one in humerus, ulna, calcaneus and fibula each). Mean duration of symptoms till surgery was 7.66(1-24) months. Eleven (45.83\%) patients underwent curettage, while 13(54.17\%) patients received RFA Mean age of patients in curettage group was 12.1(3-18) years. Three of them were female and 8 were male. Mean operation length was 69.5 (60-120) minutes. Mean hospital stay was 1.3(0-2) days. Mean follow-up time was 5.72(2-9) years. Mean age of patients in the RFA group was 10,7(2-17) years. Five of them were female and 8 were male. Mean operation length was 49.6(20-90)minutes. Mean hospital stay was $0.3(0-1)$ days. Mean follow-up time was 1.76(1-4) years. Mean operation length, hospital stay and follow-up was significantly shorter in the RFA group. All data of the patients are outlined on Table 1

Two patients (18.1\%) in the curettage group had recurrence. One of the cases was a 3 years old male child with a lesion in his right proximal femur. He had persistent pain in month 5 after surgery and curettage was repeated once further studies confirmed. Other case was a 13 years old female patient with a lesion in her right proximal femur. She was still symptomatic 1 month after surgery and imaging studies revealed recurring lesion. She was treated

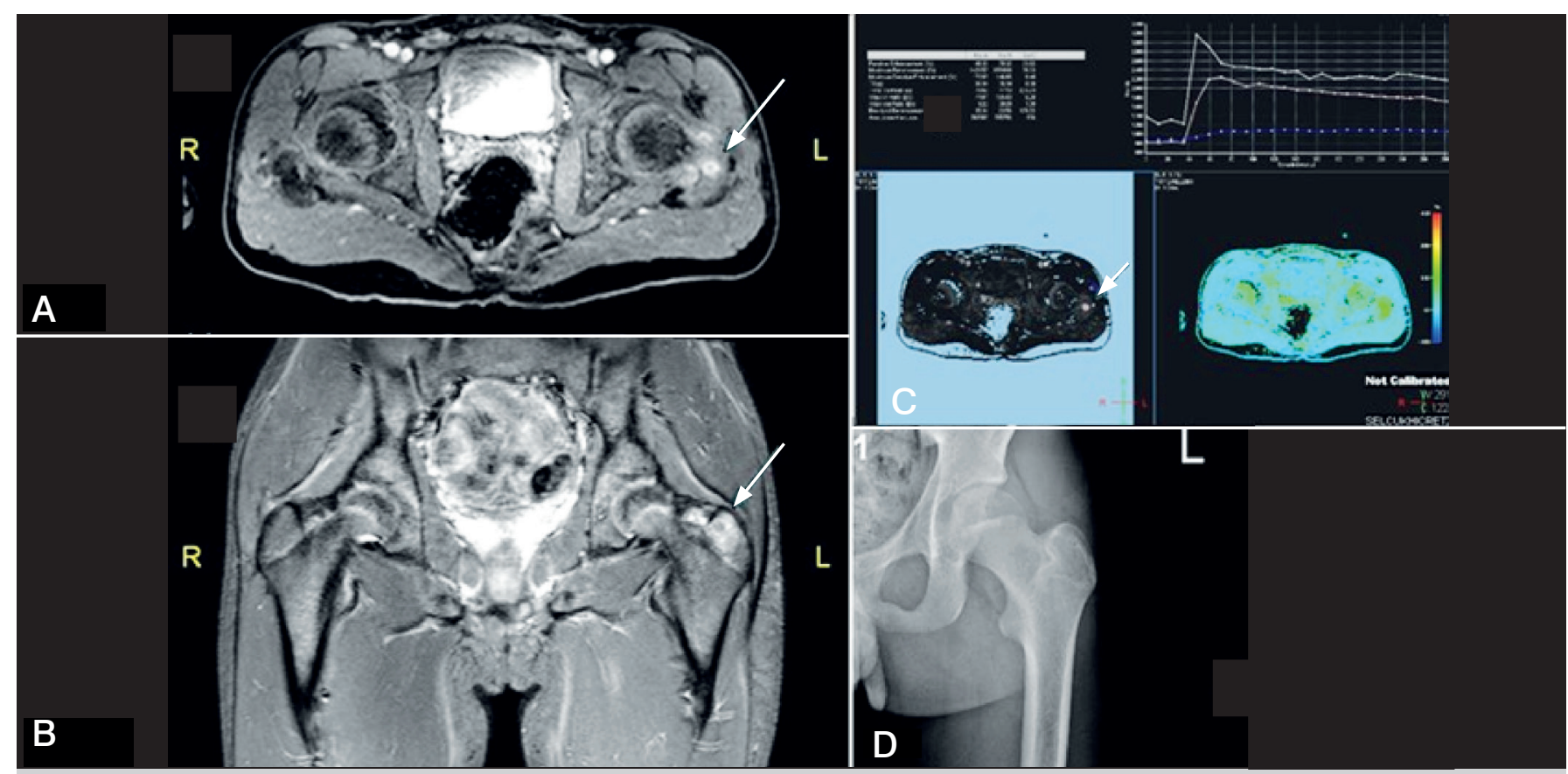

Figure 1. RFA treated 1 years old female patient preoperative (a-b), intraoperative (c), postoperative (d) 1. Year images. 


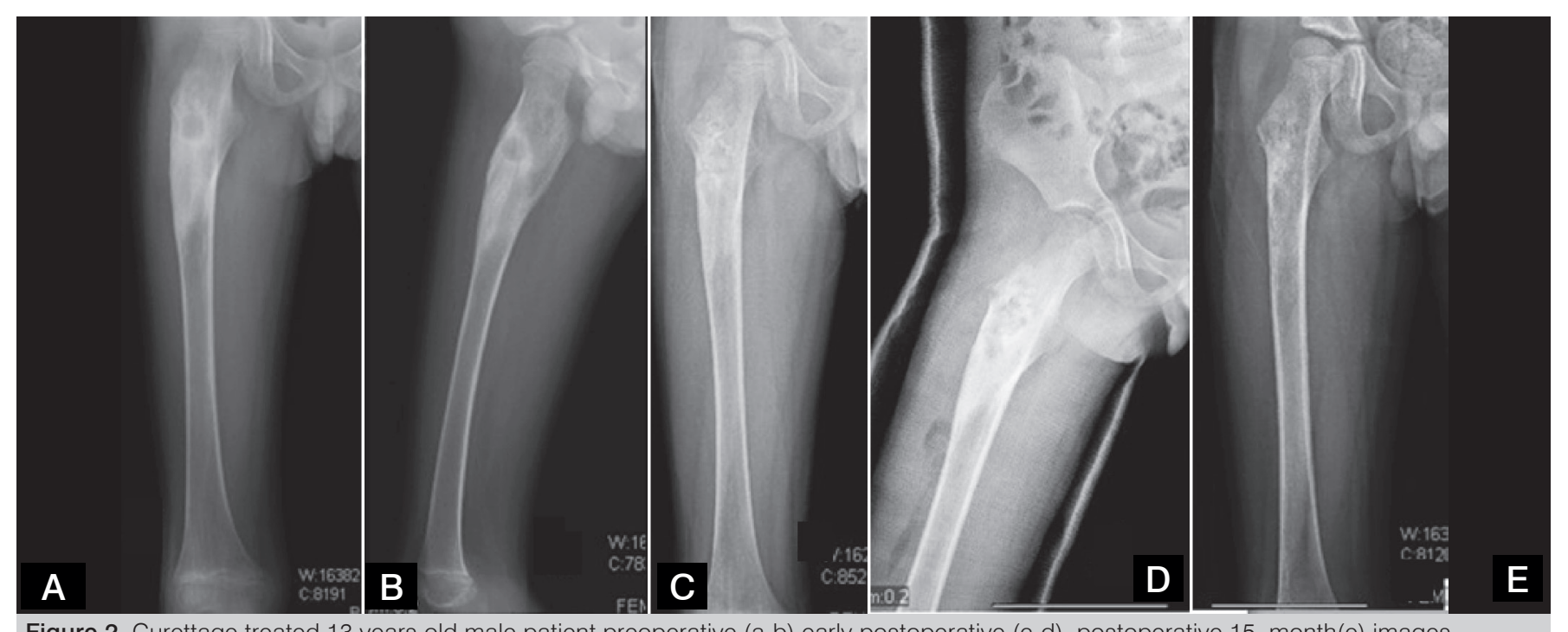

Figure 2. Curettage treated 13 years old male patient preoperative (a-b) early postoperative (c-d) postoperative 15. month(e) images.

\begin{tabular}{|c|c|c|c|}
\hline Demographic properties & curettage & $\mathrm{Rf}$ & total \\
\hline Patient & 11 & 13 & 24 \\
\hline Age(mean)(yr) & $12,1(3-18)$ & $10,7(2-17)$ & $11(2-18)$ \\
\hline $\operatorname{Sex}(F-M)$ & $3-8$ & $5-8$ & 8-16 \\
\hline $\begin{array}{c}\text { Duration of symptoms } \\
\text { (mean)(month) }\end{array}$ & $9,54(5-24)$ & $6,07(1-14)$ & $7,66(1-24)$ \\
\hline Operation time(mean)(min) & $69,5(60-120)$ & $49,6(20-90)$ & $58,7(20-120)$ \\
\hline $\begin{array}{l}\text { Lengt of hospital(mean) } \\
\text { (day) }\end{array}$ & $1,3(0-2)$ & $0,3(0-1)$ & $0,75(0-2)$ \\
\hline Follow up time(mean) (yr) & $5,72(2-9)$ & $1,76(1-4)$ & $3,58(1-9)$ \\
\hline Recurrence & 2 & 2 & 4 \\
\hline \multicolumn{4}{|l|}{ Localisation } \\
\hline Femur & 7 & 6 & 13 \\
\hline Tibia & 1 & 6 & 7 \\
\hline Other & 3 & 1 & 4 \\
\hline
\end{tabular}

more common than open surgery. ${ }^{5-10}$ We have been using mainly radiofrequency in our clinic for the last four years.

Operative length in open surgery is typically longer as it takes time for exposure and wound closure. Need for increased soft tissue dissection and osseous manipulation in open surgery causes more postoperative pain and lengthens hospital stay. ${ }^{7,9,11}$ Lindner has compared percutaneous drilling to conventional methods and stated that hospital stay was shorter with the percutaneous approach.9 Similarly, Rosenthal has compared radiofrequency to open methods and reported hospital stay lengths of 4,7 and 0.18 days for open approach and RFA consecutively. 7 Yildiz have stated that mean hospital stay was 5 days while percutaneous interventions were performed as outpatient procedures. ${ }^{12}$

Main aim of osteoid osteoma treatment is complete excision of the nidus and weaning of symptoms. Complete excision may not always be possible because of lesion's small size and surrounding sclerotic bone, resulting in recurrence. Recurrence is still a major problem despite intraoperative use of advanced imaging techniques. Literature reports 5-25\% recurrence with different treatment modalities. $2,13,14$ In our study, recurrence rates were $18,1 \%$ for curettage and $15,3 \%$ for RFA. Rosenthal has reported recurrence in $9 \%$ of cases with open procedures, where as this rate was $12 \%$ with RFA. ${ }^{7}$ In his study on conventional treatment of osteoid osteoma, Yildiz had recurrence rate of $5 \% .{ }^{12}$ Bourgault has conducted a study on CT guided RFA of osteoid osteoma and reported $10.4 \%$ recurrence. ${ }^{2}$ Recurrences tend to occur during the first 2 years following surgery. $2,7,10$ Since we have switched mainly to RFA for treatment of osteoid osteoma, follow-up lengths have been shortened. Current literature reports a similar trend with use of less invasive methods, which is disadvantageous to detect recurrence since it can happen during a two year period. Long-term follow ups of RFA need to be analyzed to claim a success, since recurrence can occur in a two year period

Interventions to osteoid osteoma lesions are performed by both orthopedists and radiologists. While radiologists performed procedures under CT and MRI guidance, orthopedists preferred C-arm fluoroscopy and $\mathrm{CT}^{1,2,7,11,15}$ Recurrence rates are similar among different procedures and type of instruments. CT scan is useful because tumor size is small. Disadvantages of CT scan are problems with radiologic suite sterility, radiation, accuracy and increased intra and postoperative complications. ${ }^{16-18}$ 
The main advantage of open procedure is the possibility of histopathological diagnosis. This is not possible with percutaneous interventions. however, several authors conclude that clinical and radiological examination are adequate for diagnosis and pathological essay is not mandatory. ${ }^{14,19}$ This will reduce patient costs also. Nevertheless, histopathological examination is still recommended for lesion on atypical sites. ${ }^{20,13}$
Most of the studies in the literature are case series of a single type of treatment method. Comparative studies such as ours are extremely rare. In this study, recurrence rates of two different modalities were found to be similar. Operation and hospitalization length were shorter with RFA. When reduced costs due to shorter hospitalization and the ability to reach anatomically difficult locations are also considered percutaneous procedures are likely to replace conventional open approach.

AUTHORS' CONTRIBUTIONS: Each author contributed individually and significantly to the development of the manuscript. BS (0000-0003-4071-8052) and FG (0000-0002-2672-2904)* were the main contributors in the drafting of the manuscript. BS,FG, CE (0000-0001-8259-3695)* and AA (0000-00029730-5454)* underwent surgery, followed patients and gathered clinical data. FG,AA and UHG (0000-0002-8151-3371)* evaluated the data of the statistical analysis. FG,UHG and CE performed the literature search, review of the manuscript and contributed to the intellectual concept of the study. ${ }^{*}$ ORCID (Open Researcher and Contributor ID)

\section{REFERENCES}

1. Campanacci M, Ruggieri P, Gasbarrini A, Ferraro A, Campanacci L. Osteoid osteoma. Direct visual identification and intralesional excision of the nidus with minimal removal of bone. J Bone Joint Surg Br. 1999;81(5):814-20.

2. Bourgault C, Vervoort T, Szymanski C, Chastanet P, Maynou C. Percutaneous $\mathrm{CT}$-guided radiofrequency thermocoagulation in the treatment of osteoid osteoma: a 87 patient series. Orthop Traumatol Surg Res. 2014;100(3):323-7.

3. Boscainos PJ, Cousins GR, Kulshreshtha R, Oliver TB, Papagelopoulos PJ. Osteoid osteoma. Orthopedics. 2013;36(10):792-800.

4. Ghanem I. The management of osteoid osteoma: updates and controversies. Curr Opin Pediatr. 2006;18(1):36-41.

5. De Palma L, Candelari R, Antico E, Politano R, Luniew E, Giordanengo M, et al. Treatment of osteoid osteoma with CT-guided percutaneous radiofrequency thermoablation. Orthopedics. 2013;36(5):e581-7.

6. Flanagin BA, Lindskog DM. Intraoperative radiofrequency ablation for osteoid osteoma. Am J Orthop (Belle Mead NJ). 2015;44(3):127-30.

7. Rosenthal DI, Hornicek FJ, Wolfe MW, Jennings LC, Gebhardt MC, Mankin HJ Percutaneous radiofrequency coagulation of osteoid osteoma compared with operative treatment. J Bone Joint Surgery Am. 1998;80(6):815-21.

8. Simon MA. Percutaneous radiofrequency coagulation of osteoid osteoma compared with operative treatment. J Bone Joint Surg Am. 1999;81(3):437-8.

9. Lindner NJ, Scarborough M, Ciccarelli JM. CT-controlled thermocoagulation of osteoid osteoma in comparison with raditional methods. Z Orthop Ihre Grenzgeb. 1997;135(6):522-7.

10. Rimondi E, Mavrogenis AF, Rossi G, Ciminari R, Malaguti C, Tranfaglia C, et al. Radiofrequency ablation for nonspinal osteoid osteomas in 557 patients. Eur Radiol. 2012;22(1):181-8.

11. Maurer MH, Gebauer B, Wieners G, De Bucourt M, Renz DM, Hamm B, et al.
Treatment of osteoid osteoma using CT-guided radiofrequency ablation versus MR-guided laser ablation: a cost comparison. Eur J Radiol. 2012;81(11):e1002-6.

12. Yildiz Y, Bayrakci K, Altay M, Saglik Y. Osteoid osteoma: the results of surgica treatment. Int Orthop. 2001;25(2):119-22.

13. Rosenthal DI, Hornicek FJ, Torriani M, Gebhardt MC, Mankin HJ. Osteoid osteoma: percutaneous treatment with radiofrequency energy. Radiology. 2003;229(1):171-5.

14. Lindner NJ, Ozaki T, Roedl R, Gosheger G, Winkelmann W, Wortler K. Percutaneous radiofrequency ablation in osteoid osteoma. J Bone Joint Surg Am. 2001;83(3):391-6.

15. Çakar M, Esenyel CZ, Seyran M, Tekin AÇ, Ada $\square$ M, Bayraktar MK, et al. Osteoid osteoma treated with radiofrequency ablation. Adv Orthop. 2015;2015:807274.

16. Rajasekaran S, Karthik K, Chandra VR, Rajkumar N, Dheenadhayalan J. Role of intraoperative 3D C-arm-based navigation in percutaneous excision of osteoid osteoma of long bones in children. J Pediatr Orthop B. 2010;19(2):195-200.

17. Gangi A. The treatment of osteoid osteoma: a multitude of choice: surgery, percutaneous resection, alcohol injection or thermocoagulation. J Radiol. 1999;80(5):419-20.

18. Kendoff D, Hufner T, Citak M, Geerling J, Mossinger E, Bastian L, et al. Navigated Iso-C3D-based percutaneous osteoid osteoma resection: a preliminary clinical report. Comput Aided Surg. 2005;10(3):157-63.

19. Akhlaghpoor S, Ahari AA, Shabestari AA, Alinaghizadeh MR. Radiofrequency ablation of osteoid osteoma in atypical locations: a case series. Clin Orthop Relat Res. 2010;468(7):1963-70.

20. Rosenthal DI, Hornicek FJ, Wolfe MW, Jennings LC, Gebhardt MC, Mankin HJ. Decreasing length of hospital stay in treatment of osteoid osteoma. Clin Orthop Relat Res. 1999;(361):186-91. 